\title{
KONSEP KEADILAN DALAM PERSPEKTIF FILSAFAT HUKUM ISLAM
}

\author{
Mahir Amin \\ Fakultas Syari'ah dan Hukum UIN Sunan Ampel Surabaya | \\ maheraminzein@gmail.com
}

\begin{abstract}
This article discusses about the concept of justice in the perspective of the philosophy of Islamic law. Philosophically, there are two formulations of justice: first, the view that what is meant by justice is a harmony between the use of right and obligation are in line with the implementation of the proposition of "the balance of law" or "the dose of right and obligation"; second, the view of the lawyers who formulate that justice is a harmony between legal certainty and proportionality of law. Justice, in Islamic law, is derived from the Most Just. It is because Allah SWT is the upholder of justice, then He must be believed not to apply unjust to His servants. The concept of justice, based on al-Shatibi's maqasid al-shari'ah theory, is determined by the benefits which are divided into three, namely daruriyyat (necessities), hajiyyat (needs), and tahsiniyyat (luxuries). This indicates that Islam is concerned with the issue of justice. The conception of justice will continue to evolve in line with the social development. Construction of law and justice in Islam cannot be separated from morality and transcendental beliefs since these aspects are intertwined.
\end{abstract}

Keywords: Justice, philosophy, law, Islam.

Abstrak: Artikel ini membahas tentang konsep keadilan dalam perspektif filsafat hukum Islam. Secara filsafat, terdapat dua rumusan tentang keadilan: Pertama, pandangan bahwa yang dimaksudkan dengan keadilan itu ialah keserasian antara penggunaan hak dan pelaksanaan kewajiban selaras dengan dalil "neraca hukum" yakni "takaran hak dan kewajiban". Kedua, pandangan para ahli hukum yang pada dasarnya merumuskan bahwa keadilan itu adalah keserasian antara kepastian hukum dan kesebandingan hukum. Keadilan hukum dalam Islam bersumber dari Tuhan yang Maha Adil, karena pada hakikatnya Allah-lah yang menegakkan keadilan (qaiman bil qisth), maka harus diyakini bahwa Allah tidak berlaku aniaya (zalim) kepada hamba- 
hamba-Nya. Dalam filsafat hukum Islam, konsep keadilan dirumuskan dalam maqashid al-syari'ah yang dirumuskan al-Syatibi, bahwasanya hukum yang berlandaskan keadilan ditentukan oleh maslahat yang terbagi menjadi tiga, yaitu dharuriyyat, hajiyyat, dan tahsiniyyat. Hal tersebut menandakan bahwa Islam sangat peduli dengan masalah keadilan. Konsepsi keadilan akan terus berkembang sejalan dengan perkembangan sosial. Konstruksi hukum dan keadilan dalam Islam pun tidak dapat dilepaskan antara moralitas dan kepercayaan transendental, disebabkan aspek-aspek tersebut saling bertautan.

Kata Kunci: Keadilan, Filsafat, Hukum, Islam.

\section{Pendahuluan}

Keadilan merupakan salah satu tujuan hukum yang paling banyak dibicarakan sepanjang perjalanan filsafat hukum. Tujuan hukum bukan hanya keadilan, tetapi juga untuk kepastian hukum, dan kemanfaatan. Idealnya, hukum memang harus mengakomodasikan kegiatannya. Putusan hakim, misalnya, sedapat mungkin merupakan resultante dari ketiganya. Sekalipun demikian, tetap ada yang berpendapat, diantara ketiga tujuan yang paling penting, bahkan ada yang berpendapat merupakan tujuan hukum satu-satunya.

Diskursus tentang keadilan seringkali mengacu pada dua aliran pemikiran. Pemikiran itu adalah John Rawls dengan theory of justicenya, dan Jürgen Habermas dengan etika diskursusnya. John Rawls dan Jürgen Habermas, dalam terang filsafat kritis yang dikembangkan oleh Kant, berupaya mencari prinsip utama yang mendasari kehidupan bermasyarakat, dan karena yang mereka temukan adalah prinsip keadilan, maka mereka mencari suatu prinsip keadilan yang universal. Bagi pengkritiknya, keadilan universal sesuatu yang tidak dapat diterima karena prinsip tentang keadilan itu haruslah mendasarkan dirinya ada nilai komunitas masing-masing.

Dalam ajaran Islam, keadilan adalah ketetapan Allah bagi kosmos atau alam raya ciptaan-Nya. Keadilan adalah prinsip yang merupakan hukum seluruh hajat raya. Oleh karenanya melanggar 
keadilan adalah melanggar hukum kosmos dan dosa ketidakadilan akan mempunyai dampak kehancuran tatanan masyarakat manusia. Oleh sebab itu segala tindakan manusia harus memenuhi rasa keadilan, hal ini dalam rangka menjaga kelestarian kehidupan umat manusia.

\section{Konsep Keadilan}

Keadilan merupakan terma yang tak asing terdengar di telinga kita. Setiap tindakan yang menuntut kesaman hak dalam pemenuhan kewajiban "keadilan" menjadi hal yang terpisahkan. Secara definitif memahai arti keadilan tidak begitu sulit karena terdapat beberapa perumusan sederhana yang dapat menjawab tentang pengertian keadilan. Namun untuk memahami tentang makna keadilan tidaklah semudah membaca teks pengertian tentang keadilan yang diberikan oleh para pakar, karena ketika berbicara tentang makna berarti sudah bergerak dalam tataran filosofis yang perlu perenungan secara mendalam sampai pada hakikat yang paling dalam. ${ }^{1}$

Terdapat dua rumusan tentang keadilan: Pertama, pandangan bahwa yang dimaksudkan dengan keadilan itu ialah keserasian antara penggunaan hak dan pelaksanaan kewajiban selaras dengan dalil "neraca hukum" yakni "takaran hak dan kewajiban". Kedua, pandangan para ahli hukum yang pada dasarnya merumuskan bahwa keadilan itu adalah keserasian antara kepastian hukum dan kesebandingan hukum. ${ }^{2}$

Keserasian antara penggunaan hak dan pelaksanaannya berdasarkan dalil takaran hak adalah kewajiban:

1. Hak setiap orang itu besar kecilnya tergantung pada atau selaras dengan besar kecil kewajibannya.

2. Dalam keadaan yang wajar, tidaklah benar kalau seseorang dapat memperoleh haknya secara tidak selaras dengan

' Angkasa, Filsafat Hukum, (Purwokerto: Universitas Jenderal Soedirman, 20 I 0), 105.

2 A. Ridwan Halim, Pengantar Ilmu Hukum Dalam Tanya Jawab, (Jakarta: Ghalia Indonesia, 2005), 176. 
kewajibannya atau tidak pula selaras kalau seseorang itu dibebankan kewajiban yang tidak selaras dengan haknya.

3. Tiada seorangpun dapat memperoleh haknya tanpa ia melaksanakan kewajibannya, baik sebelum maupun sesudahnya, dan dengan demikian pula sebaliknya tiada seorangpun yang dapat dibebankan kewajibannya tanpa ia memperoleh haknya, baik sebelum maupun sesudahnya. Misalnya setiap pemilik benda atau pemegang hak milik atas suatu benda harus membayar pajak kekayaannya atas benda miliknya itu dalam jumlah tertentu yang ditentukan menurut harga atau nilai bendanya tersebut. Semakin mahal harga atau nilai benda tersebut, maka semakin mahal pula pajak yang harus dibayar oleh pemiliknya dan demikian pula sebaliknya. Demikian juga halnya upah seorang pegawai tentunya diselaraskan dengan berat ringan pekerjaannya ${ }^{3}$

Dalam buku Philosophy of Islamic Law and Orientalists, Muslehuddin menyitir pandangan Plato:

"In his view, justice consists in a harmonious relation, between the various parts of the social organism. Every citizen must do his duty in his appointed place and do the thing for which his nature is best suited".

Plato dalam mengartikan keadilan, sangat dipengaruhi oleh cita-cita kolektivistik yang memandang keadilan sebagai hubungan harmonis dengan berbagai organisme sosial. Setiap warga negara harus melakukan tugasnya sesuai dengan posisi dan sifat alamiahnya. ${ }^{4}$

Hegel, dalam Philosophy of Rightnya, melihat keadilan memiliki hubungan dengan solidaritas secara interdependensi. Artinya, keadilan dan solidaritas tidak dapat dipisahkan satu sama lain, kehadiran yang satu selalu sudah mengandaikan kehadiran yang lain. Keadilan merupakan realisasi dari kebebasan

\footnotetext{
${ }^{3}$ Ibid., 177.

${ }^{4}$ Muhammad Muslehuddin, Philosophy of Islamic Law and the Orientalists, (Delhi: Markaz Maktabah Islamiyah, 1985), 42.
} 
individual, sedangkan solidaritas merupakan realisasi kebebasan pada tataran sosial. Mendapat pengaruh dari Hegel maupun Kant, Habermas mempostulatkan prinsip penghormatan yang sama, dan hak yang sama bagi individu. Dari perspektif modernitas, menjadikan hak serta penghormatan yang sama bagi individu sebagai postulat merupakan realisasi kebebasan subjektif dan individualitas yang tidak dapat ditolak keberadaannya. Sedangkan tentang solidaritas, Habermas berpendapat bahwa "solidaritas mempostulatkan empati dan perhatian bagi keberlangsungan lingkungan sosial masyarakat." Dengan kata lain, "solidaritas mengacu pada keberlangsungan ikatan anggota komunitas yang secara intersubjektif menempati dunia kehidupan yang sama." ${ }^{5}$

Dalam kaca mata Hegel, moralitas berfungsi untuk melindungi baik itu kebebasan di tataran subjektif, maupun kebebasan di tataran sosial. Kebebasan subjektif, jika disintesakan dengan piranti filosofis ala Kant, mempostulatkan rasa hormat dan hak yang sama. Sementara kebebasan di tataran sosial mempostulatkan empati dan perhatian terhadap masyarakat sekitar dimana individu itu hidup dan berkembang. ${ }^{6}$ Dengan kata lain, yang pertama mempostulatkan keadilan, yang kedua mempostulatkan solidaritas. Keadilan dan solidaritas adalah elemen kehidupan sosial yang tak terpisahkan. Pandangan hegel diperkuat Habermas, bahwa keadilan dan solidaritas adalah dua muka dari keping uang logam kehidupan sosial yang sama. Karena, etika diskursus praksis komunikatif deliberatif diskursif, dan menawarkan prosedur yang membuka kemungkinan bagi setiap orang untuk mempengaruhi hasil konsensus dengan kesetujuan, maupun dengan ketidaksetujuan di satu sisi. Di sisi lain, diskursus komunikatif juga tidak merusak ikatan sosial yang merupakan latar belakang para partisipan diskursus, yang juga

${ }^{5}$ Jürgen Habermas, Moral Consciousness and Communicative Action, (Cambridge: MIT Press, 1990), 200.

${ }^{6}$ Bur Rasuanto, Keadilan Sosial: Pandangan Deontologis Rawls dan Habermas, Dua Teori Filsafat Politik Modern (Jakarta: Gramedia, tt), I50. 
menyadari keanggotaannya didalam suatu komunitas komunikasi yang "tak terbatas". ${ }^{7}$

Aristoteles, adalah seorang filosof pertama kali yang merumuskan arti keadilan. Ia mengatakan bahwa keadilan adalah memberikan kepada setiap orang apa yang menjadi haknya (fiat jutitia bereat mundus). Selanjutnya dia membagi keadilan dibagi menjadi dua bentuk yaitu: Pertama, keadilan distributif, adalah keadilan yang ditentukan oleh pembuat undang-undang, distribusinya memuat jasa, hak, dan kebaikan bagi anggotaanggota masyarakat menurut prinsip kesamaan proporsional. Kedua, keadilan korektif, yaitu keadilan yang menjamin, mengawasi dan memelihara distribusi ini melawan seranganserangan ilegal. Fungsi korektif keadilan pada prinsipnya diatur oleh hakim dan menstabilkan kembali status quo dengan cara mengembalikan milik korban yang bersangkutan atau dengan cara mengganti rugi atas miliknya yang hilang ${ }^{8}$ atau kata lainnya keadilan distributif adalah keadilan berdasarkan besarnya jasa yang diberikan, sedangkan keadilan korektif adalah keadilan berdasarkan persamaan hak tanpa melihat besarnya jasa yang diberikan.

Aristoteles dalam mengartikan keadilan sangat dipengaruhi oleh unsur kepemilikan benda tertentu. Keadilan ideal dalam pandangan Aristoteles adalah ketika semua unsur masyarakat mendapat bagian yang sama dari semua benda yang ada di alam. Manusia oleh Aristoteles dipandang sejajar dan mempunyai hak yang sama atas kepemilikan suatu barang (materi). Pandangan Aristoteles tentang keadilan bisa didapatkan dalam karyanya nichomachean ethics, politics, dan rethoric. Buku itu sepenuhnya ditujukan bagi keadilan, yang, berdasarkan filsafat hukum Aristoteles, mesti dianggap sebagai inti dari filsafat hukumnya,

7Jürgen Habermas, Justification and Application: Remarks on Discourse Ethics, (Oxfords: Polity Press, 1990), I-2.

${ }^{8}$ Dominikus Rato, Filsafat Hukum, Mencari, Menemukan, Dan Memahami Hukum, (Surabaya: LaksBang Yustisia, Surabaya, 20 I0), 64. 
"karena hukum hanya bisa ditetapkan dalam kaitannya dengan keadilan". 9

\section{Keadilan Hukum Islam}

Pada dataran empiris, sebuah teori keadilan yang diidealkan rumusannya sering kali gagal pada tingkat aplikasi, sehingga apa "yang seharusnya" menjadi lumpuh dan tak berdaya di depan apa "yang senyatanya". Begitu juga implikasi yang ditimbulkan, sehingga keadilan tinggal sebuah retorika. Padahal tujuan akhir hukum adalah keadilan. Oleh karena itu, segala usaha yang terkait dengan hukum mutlak harus diarahkan untuk menemukan sebuah sistem hukum yang paling cocok dan sesuai dengan prinsip keadilan. Dengan kata lain, adil merupakan unsur konstitutif segala pengertian tentang hukum.

Hukum adalah undang-undang yang adil. Adil merupakan unsur konstitutif dari segala pengertian hukum, hanya peraturan yang adil yang disebut hukum. Hukum melebihi negara. Negara (pemerintah) tidak boleh membentuk hukum yang tidak adil. Lebih percaya pada prinsip-prinsip moral yang dimuat dalam undang-undang dari pada kebijaksanaan manusia dalam bentuk putusan-putusan hakim. sikap kebanyakan orang terhadap hukum mencerminkan pengertian hukum ini, yaitu hukum sebagai moral hidup (norma ideal).

Prinsip-prinsip pembentukan hukum (prinsip-prinsip keadilan) bersifat etis, maka hukum sebagai keseluruhan mewajibkan secara batiniah. Karena itu tujuan akhir hukum yang berupa keadilan harus dicapai melalui sebuah institusi legal dan independen dalam sebuah negara. Hal tersebut menunjukkan pentingnya mewujudkan keadilan bagi setiap warga negara (manusia) sebagai orientasi hukum. Salah satu sumbangan terbesar Islam kepada umat manusia adalah prinsip keadilan sosial dan pelaksanaannya dalam setiap aspek kehidupan

${ }^{9}$ Carl Joachim Friedrich, Filsafat Hukum Perspektif Historis, (Bandung: Nuansa dan Nusamedia, 2004), 239. 
manusia. Islam memberikan suatu aturan yang dapat dilaksanakan oleh semua orang yang beriman. Setiap anggota masyarakat didorong untuk memperbaiki kehidupan material masyarakat tanpa membedakan bentuk, keturunan dan jenis orangnya. Setiap orang dipandang sama untuk diberi kesempatan dalam mengembangkan seluruh potensi hidupnya. ${ }^{10}$

Tidak dapat dipungkiri, al-Qur'an meningkatkan sisi keadilan dalam kehidupan manusia, baik secara kolektif maupun individual. Karenanya, dengan mudah kita lalu dihinggapi semacam rasa cepat puas diri sebagai pribadi-pribadi muslim dengan temuan yang mudah diperoleh secara gamblang itu. Sebagai hasil lanjutan dari rasa puas diri itu, lalu muncul idealisme atas al-Qur'an sebagai sumber pemikiran paling baik tentang keadilan. Kebetulan persepsi semacam itu sejalan dengan doktrin keimanan Islam sendiri tentang Allah sebagai Tuhan Yang Maha Adil. Bukankah kalau Allah sebagai sumber keadilan itu sendiri, lalu sudah sepantasnya al-Qur'an yang menjadi firmanNya (Kalam Allah) juga menjadi sumber pemikiran tentang keadilan?

Al-Qur'an menggunakan pengertian yang berbeda-beda bagi kata atau istilah yang bersangkut-paut dengan keadilan. Bahkan kata yang digunakan untuk menampilkan sisi atau wawasan keadilan juga tidak selalu berasal dari akar kata 'adl. Kata-kata sinonim seperti qisth, hukm dan sebagainya digunakan oleh alQur'an dalam pengertian keadilan. Sedangkan kata 'adl dalam berbagai bentuk konjugatifnya bisa saja kehilangan kaitannya yang langsung dengan sisi keadilan itu ( $t a^{\prime} d i l u$, dalam arti mempersekutukan Tuhan dan 'adl dalam arti tebusan).

Istilah lain dari al-'adl adalah al-qist, al-misl (sama bagian atau semisal). Secara terminologis, adil berarti mempersamakan sesuatu dengan yang lain, baik dari segi nilai maupun dari segi ukuran, sehingga sesuatu itu menjadi tidak berat sebelah dan tidak

${ }^{10}$ Afzalur Rahman, Doktrin Ekonomi Islam, jilid I, Terj. Soeroyo, Nastangin, (Yogyakarta: PT Dana Bhakti Wakaf, 1995), 74. 
berbeda satu sama lain. Adil juga berarti berpihak atau berpegang kepada kebenaran. ${ }^{11}$

Kalau dikatagorikan, ada beberapa pengertian yang berkaitan dengan keadilan dalam al-Qur'an dari akar kata 'adl itu, yaitu sesuatu yang benar, sikap yang tidak memihak, penjagaan hak-hak seseorang dan cara yang tepat dalam mengambil keputusan "Hendaknya kalian menghukumi atau mengambil keputusan atas dasar keadilan". Secara keseluruhan, pengertian-pengertian di atas terkait langsung dengan sisi keadilan, yaitu sebagai penjabaran bentuk-bentuk keadilan dalam kehidupan. Dari terkaitnya beberapa pengertian kata 'adl dengan wawasan atau sisi keadilan secara langsung itu saja, sudah tampak dengan jelas betapa porsi "warna keadilan" mendapat tempat dalam al-Qur'an.

Dalam Islam perintah berlaku adil ditujukan kepada setiap orang tanpa pandang bulu. Perkataan yang benar harus disampaikan apa adanya walaupun perkataan itu akan merugikan kerabat sendiri. Keharusan berlaku adil pun harus dtegakkan dalam keluarga dan masyarakat muslim itu sendiri, bahkan kepada orang kafir pun umat Islam diperintahkan berlaku adil. Untuk keadilan sosial harus ditegakkan tanpa membedakan karena kaya miskin, pejabat atau rakyat jelata, wanita atau pria, mereka harus diperlakukan sama dan mendapat kesempatan yang sama. ${ }^{12}$ Senada dengan itu, Sayyid Qutb menegaskan bahwa Islam tidak mengakui adanya perbedaan-perbedaan yang digantungkan kepada tingkatan dan kedudukan. ${ }^{13}$

Islam juga mengajarkan manusia agar memenuhi janji, tugas dan amanat yang dipikulnya, melindungi yang menderita, lemah dan kekurangan, merasakan solidaritas secara konkrit dengan

\footnotetext{
' Abdual Aziz Dahlan, et. all, (editor), Ensiklopedi Hukum Islam, jilid 2, (Jakarta: PT Ichtiar Baru Van Hoeve, 1997), 25.

12 Juhaya S. Praja, Filsafat Hukum Islam, (Bandung: Pusat Penerbitan Universitas LPPM UNISBA, 1995),73.

13 Sayyid Qutb, "Keadilan Sosial dalam Islam", dalam John J. Donohue dan John L. Esposito, Islam dan Pembaharuan, Terj. Machnun Husein, (Jakarta: CV Rajawali, I984), 224.
} 
sesama warga masyarakat, jujur dalam bersikap, dan seterusnya. Hal-hal yang ditentukan sebagai capaian yang harus diraih kaum Muslim itu menunjukkan orientasi yang sangat kuat akar keadilan. Demikian pula, wawasan keadilan itu tidak hanya dibatasi hanya pada lingkup mikro dari kehidupan warga masyarakat secara perorangan, melainkan juga lingkup makro kehidupan masyarakat itu sendiri. Sikap adil tidak hanya dituntut bagi kaum Muslim saja tetapi juga mereka yang beragama lain. Itupun tidak hanya dibatasi sikap adil dalam urusan-urusan mereka belaka, melainkan juga dalam kebebasan mereka untuk mempertahankan keyakinan dan melaksanakan ajaran agama masing-masing.

Yang cukup menarik adalah dituangkannya kaitan langsung antara wawasan atau sisi keadilan dengan upaya peningkatan kesejahteraan dan peningkatan taraf hidup warga masyarakat, terutama mereka yang menderita dan lemah posisinya dalam percaturan masyarakat, seperti yatim-piatu, kaum muskin, janda, wanita hamil atau yang baru saja mengalami perceraian. Juga sanak keluarga (dzawil qurba) yang memerlukan pertolongan sebagai pengejawantahan keadilan. Orientasi sekian banyak "wajah keadilan" dalam wujud konkrit itu ada yang berwatak karikatif maupun yang mengacu kepada transformasi sosial. Prinsip keadilan sosial dan pelaksanaannya dalam setiap aspek kehidupan manusia. Islam memberikan suatu aturan yang dapat dilaksanakan oleh semua orang yang beriman. Setiap anggota masyarakat didorong untuk memperbaiki kehidupan material masyarakat tanpa membedakan bentuk, keturunan dan jenis orangnya. Setiap orang dipandang sama untuk diberi kesempatan dalam mengembangkan seluruh potensi hidupnya. ${ }^{14}$

Fase terpenting dari wawasan keadilan yang dibawakan Islam adalah sifatnya sebagai perintah agama, bukan sekedar sebagai acuan etis atau dorongan moral belaka. Pelaksanaannya

\footnotetext{
${ }^{14}$ Afzalur Rahman, Doktrin Ekonomi Islam, 74.
}

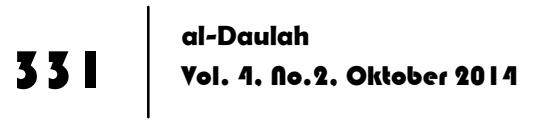


merupakan pemenuhan kewajiban agama, dan dengan demikian akan diperhitungkan dalam amal perbuatan seorang Muslim di hari perhitungan (yaum al-hisab) kelak. Dengan demikian, wawasan keadilan dalam islam dapat diterima sebagai sesuatu yang ideologis, sudah tentu dengan segenap bahaya-bahaya yang ditimbulkannya, karena ternyata dalam sejarah, keadilan ideologis cenderung membuahkan tirani yang mengingkari keadilan itu.

Sebab kenyataan penting juga harus dikemukakan dalam hal ini, bahwa sifat dasar wawasan keadilan yang dikembangkan Islam ternyata bercorak mekanistik, kurang bercorak reflektif. Ini mungkin karena "warna" dari bentuk konkrit wawasan keadilan itu adalah "warna" hukum agama, sesuatu yang katakanlah legal-formalistik yang dalam pelaksanaannya terkait dengan struktur-struktur kekuasaan dalam masyarakat, struktur-struktur mana terdapat dalam bidang politik, ekonomi, sosial, budaya, dan ideologi. Maka membangun keadilan berarti menciptakan struktur-struktur yang memungkinkan pelaksanaan keadilan. Masalah keadilan ialah bagaimanakah mengubah strukturstruktur kekuasaan yang seakan-akan sudah memastikan ketidakadilan, artinya yang memastikan bahwa pada saat yang sama di mana masih ada golongan- golongan miskin dalam masyarakat, terdapat juga kelompok-kelompok yang dapat hidup dengan seenaknya karena mereka menguasai sebagian besar dari hasil kerja dan hak-hak golongan yang miskin itu.

Penegakan keadilan menjadi tugas hukum atau merupakan kegunaan hukum. Keadilan yang menjadi tugas hukum merupakan hasil penyerasian atau keserasian antara kepastian hukum dengan kesebandingan hukum. Secara ideal kepastian hukum merupakan pencerminan azas tidak merugikan orang lain, sedangkan kesebandingan hukum merupakan pencerminan azas bertindak sebanding. Oleh karena keserasian antara kepastian hukum dengan kesebandingan hukum merupakan inti penegakan 
hukum, maka penegakan hukum sesungguhnya dipengaruhi oleh struktur dan individu-individunya.

Keadilan hukum dalam Islam bersumber dari Tuhan yang Maha Adil, karena pada hakikatnya Allah-lah yang menegakkan keadilan (qaiman bil qisth), maka harus diyakini bahwa Allah tidak berlaku aniaya (zalim) kepada hamba-hamba- Nya (Q.S. 10/Yunus: 449). Oleh karena itu setiap perbuatan manusia akan dipertanggungjawabkan kepada-Nya pada hari keadilan (Q.S. 4/alNisa: 110). Adil dalam pengertian persamaan (equality), yaitu persamaan dalam hak, tanpa membedakan siapa; dari mana orang yang akan diberikan sesuatu keputusan oleh orang yang diserahkan menegakkan keadilan, sebagaimana dimaksud firman Allah Q.S. 4/al-Nisaa': 58.

Dalam prinsip keadilan hukum ini Nabi SAW menegaskan adanya persamaan mutlak (egalitarisme absolut, al-musawah almuthlaqah) di hadapan hukum-hukum syariat. Keadilan dalam hal ini tidak membedakan status sosial seseorang, apakah ia kaya atau miskin, pejabat atau rakyat jelata, dan tidak pula karena perbedaan warna kulit serta perbedaan bangsa dan agama, karena di hadapan hukum semuanya sama.

Konsep persamaan yang terkandung dalam keadilan tidak pula menutup kemungkinan adanya pengakuan tentang kelebihan dalam beberapa aspek, yang dapat melebihkan seseorang karena prestasi yang dimilikinya. Akan tetapi kelebihan tersebut tidaklah akan membawa perbedaan perlakuan hukum atas dirinya. Pengakuan adanya persamaan, bahkan dalam al-Qur'an dinyatakan sebagai "pemberian" Allah yang mempunyai implikasi terhadap tingkah laku manusia, adalah bagian dari sifat kemuliaan manusia (al-karamah al-insaniyah), yang juga bagian dari ketetapan Tuhan (Q.S. 17/al-Isra: 70).

\section{Maqasid al-Syari'ah, Upaya Menggali Nilai Keadilan}

Salah satu hal yang mendasari pemikiran maqashid syari'ah sebagai instrumen menggali nilai keadilan hukum adalah tujuan 
ditetapkannya hukum Islam. Maqashid syari'ah penting untuk difahami, karena dengannya wawasan kita tentang hukum Islam menjadi komprehensif. Seseorang tidak dapat dikatakan mampu menetapkan hukum dalam Islam, sebelum ia memahami benar tujuan Allah mengeluarkan perintah-perintah dan laranganlarangan-Nya. Maqashid Asy-Syari'ah adalah: tujuan yang menjadi target nash dan hukum-hukum partikular untuk direalisasikan dalam kehidupan manusia, baik berupa perintah, larangan, dan mubah. Untuk individu, keluarga, jamaah dan umat. ${ }^{15}$

Tujuan hukum menurut al-Juwaini ada tiga macam, yaitu primer, sekunder, dan tersier. Pemikiran Al-Juwaini tersebut dikembangkan oleh muridnya, Al-Ghazali. Al-Ghazali menjelaskan maksud hukum dalam kaitannya dengan pembahasan tema maslahat. Maslahat menurut Al-Ghazali adalah memelihara agama, jiwa, akal, keturunan, dan harta. Kelima macam maslahat di atas bagi Al-Ghazali berada pada skala prioritas dan urutan yang berbeda jika dilihat dari sisi tujuannya, yaitu peringkat primer, sekunder, dan tersier. ${ }^{16}$

Tujuan hukum bisa juga disebut dengan hikmah-hikmah dibalik hukum itu sendiri. Karena dalam setiap hukum yang disyari'atkan oleh Allah untuk hambaNya pasti terdapat hikmah. Ada perbedaan pemahaman hikmah dan illat hukum (motif penetapan hukum) yang disebutkan oleh para ahli ushul fikih dalam bab qiyas dan didefinisikan dengan "sifat yang jelas, tetap, dan sesuai dengan hukum." Illat sesuai dengan hukum, tetapi ia bukan tujuan dari hukum itu. ${ }^{17}$

'Illat rukhsah ketika dalam perjalanan jauh baik dalam bentuk jama'-qashar atau berbuka puasa pada bulan Ramadhan adalah perjalanan itu sendiri (safar) sedang hikmah rukhsah karena adanya kesusahan yang dirasakan sewaktu dalam perjelanan itu.

\footnotetext{
${ }^{15}$ Yusuf Qardhawi, Fiqh Maqasid Syariah, (Pustaka Al-Kautsar, 2007), 18.

${ }^{16}$ Muhammad Hashim Kamali, Shariah Law: An Introduction, (Oxford: Oneworld Publications, 2008), 127.

${ }^{17}$ Yusuf Qardhawi, Fiqh Maqasid Syariah, 18.
} 
Para ahli ushul fikih tidak menyatukan antara illat hukum dan hikmah kerana hikmah sulit untuk ditetapkan contohnya jika kesusahan itu i'llat, mungkin ada orang yang mengatakan saya tidak susah.

Dalam pandangan Dr Yusuf Qardhawi bahwa tujuan hukum dapat dicapai dengan beberapa cara; Meneliti setiap 'illat nash AlQuran dan As-Sunnah. Meneliti, mengikuti, dan memikirkan hukum-hukum partikular. Untuk kemudian menyatukan antara satu hukum dengan hukum yang lain agar dari penelitian ini kita dapat ditemukan tujuan hukum yang menjadi maksud Allah dalam membuat hukum-hukum tersebut.

Ibnu Qayyim menjelaskan bahwa Tujuan Hukum Islam adalah untuk mewujudkan hamba dunia dan akhirat. Menurutnya, seluruh hukum itu mengandung keadilan, rahmat, kemashlahatan dan Hikmah, jika keluar dari keempat nilai yang dikandungnya, maka hukum tersebut tidak dapat dinamakan Hukum Islam. ${ }^{18}$ Hal senada juga dikemukakan oleh al-Syatibi, Ia menegaskan bahwa semua kewajiban diciptakan dalam rangka merealisasikan kemashlahatan hamba. Tak satupun hukum Allah yang tidak mempunyai tujuan. Hukum yang tidak mempunyai tujuan sama juga dengan taklif ma la yutaq' (membebankan sesuatu yang tidak dapat dilaksanakan). ${ }^{19}$ Dalam rangka mewujudkan kemashlahatan dunia dan akhirat itulah, maka para ulama Ushul Fiqh merumuskan tujuan hukum Islam tersebut kedalam lima misi, semua misi ini wajib dipelihara untuk melestarikan dan menjamin terwujudnya kemashlahatan. Kelima misi (Maqashid al-

\footnotetext{
${ }^{18}$ Ibn Qayyim, I'lam al-Muwaqii'in Rabb al- 'Alamin, (Beirut: Dar al-Jayl, t.th.), jilid III h.3. lihat juga Izzuddin Ibn Abd al-salam, Qawaid al-Ahkam fi Mashalih al-Anam, (Bairut: Dar al-Jail, t.thn), jilid II, 72. Wahbah Zuhaili, Ushul al-Figh al-Islami, (Beirut: Dar al-Fikr, 1986), Jilid II, 1017.

${ }^{19}$ Al- Syatiby, al-Muwafaqat fi Usul al-Syari'ah, (Kairo: Mustafa Muhammad, t.th.), I 50. lebih lanjut tentang tujuan hukum islam dapat dilihat dalam Fathi al-daraini, al-manahij al-Usuliyyah fi litihad bi al-Ra'yi fi al-Tasyri', (Damaskus: Dar al-Kitab al-Hadis, 1975), 28; Muhammad Abu Zahrah, Usul al-Fiqh, (Mesir: Dar al-Fikri al-Arabi, 1958), 366; Muhammad Khalid Mas'ud, Islamic Legal Philosophiy, (Islamabad; Islamic Research institute, 1977), 223.
} 
Syari'ah/Maqashid al-Khamsah) dimaksud adalah memelihara agama, jiwa, aqal, keturunan dan harta. ${ }^{20}$

Untuk mewujudkan dan memelihara kelima unsur pokok itu, al-Syatibi membagi kepada tiga tingkat, dharuriyat, hajiyat dan tahsiniyat. Pengelompokan ini didasarkan pada kebutuhan dan skala prioritas. Urutan level ini secara hirarkhis akan terlihat kepentingan dan siknifikansinya, manakala masing-masing level satu sama lain saling bertentangan. Dalam konteks ini level dharuriyyat menempati peringkat pertama disusul hajiyyat dan tahsiniyyat. level dharuriyat adalah memelihara kebutuhan yang bersifat esensial bagi kehidupan manusia. Bila kebutuhan ini tidak terpenuhi akan mengancam eksistensi kelima tujuan diatas. Sementara level hajiyyat tidak mengancam hanya saja menimbulkan kesulitan bagi manusia. Selanjutnya pada level tahsiniyyat, adalah kebutuhan yang menunjang peningkatan martabat seseorang dalam masyarakat dan dihadapan Allah Swt. Sebagai contoh, dalam memelihara unsur Agama, aspek daruriyyatnya antara lain mendirikan Shalat, shalat merupakan aspek dharuriyyat, keharusan menghadap ke kiblat merupakan aspek hajiyyat, dan menutup aurat merupakan aspeks tahsiniyyat. 21 Ketiga level ini, pada hakikatnya adalah berupaya untuk memelihara kelima misi hukum Islam.

Pemikir dan ahli teori hukum Islam berikutnya yang secara khusus membahas maqashid syari'ah adalah Izzuddin ibn Abd alSalam dari kalangan Syafi'iyah. Ia lebih banyak menekankan dan mengelaborasi konsep maslahat secara hakiki dalam bentuk menolak keburukan dan menarik manfaat. Menurutnya, maslahat keduniaan tidak dapat dilepaskan dari tiga tingkat urutan skala prioritas, yaitu primer, sekunder, dan tersier. Lebih jauh lagi ia

${ }^{20}$ Imam Abi Hamid Muhammad bin Muhammad al-Ghazali, al-Mustasfa min 'Ilm al-Usul, (Beirut: Dar al-Fikr, t.th), 20.

${ }^{21}$ Asafri Jaya Bakri, Konsep Maqashid Syari'ah menurut al-Syatibi, (Jakarta: Logos wacana IImu, 1997), 72. 
menjelaskan, bahwa hukum harus bermuara pada terwujudnya maslahat manusia, baik di dunia maupun di akhirat. ${ }^{22}$

Pembahasan maqashid syari'ah dilakukan asy-Syatibi secara khusus, sistematis, dan jelas. Ia secara tegas mengatakan bahwa tujuan utama Allah menetapkan hukum-Nya adalah untuk terwujudnya maslahat hidup manusia, baik di dunia maupun di akhirat. Oleh karena itu, hukum harus mengarah pada dan merealisasikan terwujudnya kemaslahatan. Doktrin maqasid syari'ah adalah satu, yaitu mashlahah atau kebaikan dan kesejahteraan umat manusia baik di dunia maupun diakhirat. Oleh karena itu Asy-Syatibi meletakkan posisi maslahat sebagai 'illat hukum atau alasan pensyariatan hukum Islam. ${ }^{23}$

Asy-Syathibi menyebutkan tiga (3) syarat yang diperlukan untuk memahami maqashid Syari'ah. Ketiga syarat itu adalah: 1 . Memiliki pengetahuan tentang Bahasa Arab: lafaz 'am, lafaz Khas, musytarak, haqiqat, majaz, dilalah lafaz, dan nasakh. 2. Memiliki pengetahuan tentang Sunnah. 3. Mengetahui sebab-sebab turunnya Ayat.

Seperti halnya pemikir sebelumnya, ia juga membagi urutan dan skala prioritas maslahat menjadi tiga urutan peringkat, yaitu primer, sekunder, dan tersier. Yang dimaksud maslahat menurutnya seperti halnya konsep Al-Ghazali, yaitu memelihara lima hal pokok: agama, jiwa, akal, keturunan, dan harta. Konsep maqashid syari'ah atau maslahat yang dikembangkan oleh AsySyatibi di atas sebenarnya telah melampaui pembahasan pemikir abad-abad sebelumnya. Konsep maslahat Asy-Syatibi tersebut melingkupi seluruh bagian syariah dan bukan hanya aspek yang tidak diatur oleh teks. Sesuai dengan pernyataan Al-Ghazali, AsySyatibi merangkum bahwa tujuan Allah menurunkan syariah adalah untuk mewujudkan maslahat. Meskipun begitu, pemikiran maslahat Asy-Syatibi ini tidak seberani gagasan At-Tufi.

${ }^{22}$ Yusuf Qardhawi, Fiqh Maqasid Syari'ah, 136.

${ }^{23}$ Al- Syatibiy, al-Muwafaqat fi Usul al-Syari'ah, 2-3. 
Pandangan At-Tufi mewakili pandangan yang radikal dan liberal tentang maslahat. At-Tufi berpendapat bahwa prinsip maslahat dapat membatasi Quran, Sunnah dan konsensus jika penerapan teks Quran, Sunah dan konsensus itu akan menyusahkan manusia. Akan tetapi, ruang lingkup dan bidang berlakunya maslahat At-Tufi tersebut adalah hubungan antar sesama manusia. ${ }^{24}$

Dalam menempatkan Illat sebagai maslahah An-Nabhani berbeda dengan as-Syatibi, An-Nabhani misalnya beliau dengan hati-hati menekankan berulang-ulang, bahwa maslahat itu bukanlah 'illat atau motif (al-ba'its) penetapan syariat, melainkan hikmah, hasil (natijah), tujuan (ghayah), atau akibat ('aqibah) dari penerapan syariat. ${ }^{25}$ Mengapa An-Nabhani mengatakan hikmah tidak dikatakan 'illat? Karena menurut ia nash ayat-ayat yang ada jika dilihat dari segi bentuknya (shighat) tidaklah menunjukkan adanya 'illat (al-'illiyah), namun hanya menunjukkan adanya sifat rahmat (maslahat) sebagai hasil penerapan syariat. Misalnya firman Allah Swt dalam Alqur'an Surat Al-Isra (17) ayat 82 dan al-Anbiya ayat 107 yang berbunyi: "Dan Tiadalah Kami mengutus kamu, melainkan untuk (menjadi) rahmat bagi semesta alam". Menurut An-Nabhani, ayat ini tidak mengandung shighat ta'lil (bentuk kata yang menunjukkan 'illat), misalnya dengan adanya lam ta'lil. Jadi maksud ayat ini, bahwa hasil (al-natijah) diutusnya Muhammad saw adalah akan menjadi rahmat bagi umat manusia. Artinya, adanya rahmat (maslahat) merupakan hasil pelaksanaan syariat, bukan 'illat dari penetapan syariat.

Untuk mewujudkan kemashlahatan itu, menurut Muhammad Said Ramadhan al Buthi ada lima kriteria yang harus dipenuhi, yaitu pertama memperiotaskan tujuan-tujuan Syara, kedua tidak bertentangan dengan al Qur'an, ketiga tidak bertentangan dengan al Sunnah, keempat tidak bertentangan dengan prinsip qiyas

\footnotetext{
${ }^{24}$ Muhammad Hashim Kamali, Shariah Law: An Introduction, I36-I4I.

25 Taqiyuddin An-Nabhani, Asy-Syakhshiyah al-Islâmiyyah. Ushûl al-Figh.(Al-Quds: Min Mansyurat Hizb at-Tahrir. 1953), Juz, III, h. 359-360.
} 
karena qiyas merupakan salah satu cara dalam menggali hukum yang intinya adalah untuk memberikan kemashlahatan bagi mukallaf. Dan kelima, memperhatikan kemashlahatan yang lebih besar. ${ }^{26}$ Kemudian bagaimana penerapan teori maqashid Syariah ini dalam menemukan nilai keadilan? Dalam kaitan dengan hal tersebut tentu teori maqashid al Syari'ah harus mampu menemukan fakta-fakta yang sebenarnya melalui analisis filosofis terhadap persoalan yang sedang dihadapi.

Perumusan masalah dalam proses penerapan hukum yang tepat dan benar perlu menjadi perhatian penting. Menurut Taufik, SH, mantan Hakim Agung/Mantan Wakil Ketua Mahkamah Agung RI, apabila perumusan masalah dalam suatu perkara salah, maka proses selanjutnya akan salah ${ }^{27}$. Dalam merumuskan masalah yang perlu diperhatikan adalah melakukan identifikasi terhadap masalah itu. Kemudian kategorisasi dalam menentuan metode yang akan digunakan dalam menyelesaikan masalah, sehingga nilai keadilan yang didealkan dapat tercapai. Penerapan maqashid Syari'ah dalam bingkai bagaimana menemukan kemashlahatan hukum yang akan dicapai. Sehingga dalam penyelesaian masalah bukan menang kalah, namun idealisme penegakan kebenaran, sesuai dengan fakta-fakta. (qul al haq walau kana murro).

Hubungan antara maslahah dan keadilan memang tidak mudah dipahami apabila hal tersebut tidak dihubungankan melalui aspek teologis yang membangun paradigma hukum Islam. Kalangan Mu'tazilah mengajukan kebaikan umum sebagai inti ajaran hukum Islam, yang di dalamnya mengandung nilai keadilan dan maslahah sekaligus. Akan tetapi, meskipun diakui sebagai sesuatu yang dikandung hukum Islam, keadilan sebagai

\footnotetext{
26 Muhammad Said Ramadhan al-Buti, al-Dawabit al-Mashlahat fi al Syariahh al-Islamiyah, (Beirut: Muassasah al-Risalah, 1977), I 19-248.

${ }^{27}$ Andi Syamsu Alam, "Peningkatan Kualitas Putusan Hakim Peradilan Agama Tingkat Pertama dan Tingkat Banding", dalam Majalah Varia Peradilan, (Jakarta: Ikatan Hakim Indonesia (IKAHI), Tahun Ke XXNo. 239 Agustus 2005), 4 I.
} 
sebuah pembahasan hukum akan sulit dijumpai kitab-kitab ushul fiqh. Ushul fiqh (yurisprudensi Islam) memberikan petunjuk mengenai hubungan Tuhan dengan manusia, posisi Tuhan sebagai pemberi hukum dan berbagai kaedah yang menjabarkan bagaimana kehendak Tuhan dalam Alquran dan penjelasan Nabi dipahami.

Keadilan dalam penjelasan tersebut masuk dalam kategori hukum substantif. Keadilan didefinisikan dalam sudut pandang teologis, hubungan Tuhan dengan manusia bersifat vertikal. Allah sebagai Maha Adil dan Maha Benar lebih mengetahui kebenaran dan keadilan hakiki. Manusia harus selalu menemukan keadilan dan kebenaran yang dianugerahkan Tuhan melalui proses ijtihad. Prinsip keadilan meniscayakan penggunaan rasio untuk membuat perbandingan antara satu kasus yang tidak diterangkan oleh Firman Tuhan atau sabda Nabi dengan kasus lain yang telah memiliki legitimasi hukum. Dengan cara itu, hukum Islam berkembang dan menjangkau kasus-kasus hukum yang lebih luas berdasarkan prinsip persamaan.

Teori-teori hukum Islam memang tidak memilah secara tegas antara hukum positif dan moralitas. ${ }^{28}$ Konstruksi nalar Islam tentang hukum dan keadilan merepresentasikan pandangan yang mengaitkan keadilan dengan kebenaran. Bertindak adil adalah bertindak secara benar. Mencari keadilan sama dengan mencari kebenaran. Kebenaran adalah representasi dari kehendak Tuhan kepada manusia yang dijabarkan melalui al-ahkam al-khamsah, yaitu wajib, sunnah, mubah, makruh, dan haram. Keadilan substansif dalam hukum Islam selalu dikaitkan dengan kehendak pembuat syara' (Allah) terhadap manusia, baik kehendak tersebut dipahami melalui deduksi logis (kaedah lughawiyyah), deduksi

\footnotetext{
${ }^{28}$ Keadilan sebagai sebuah nilai moral memiliki ciri khas karena watak tuntutan moralnya yang berbeda dengan tuntutan moral lain. Moralitas keadilan selalu terkait dengan manusia satu dengan manusia lain berdasarkan ukuran perbandingan dalam pemberian perlakuan oleh otoritas publik. Lihat Manzoor Ahmad, Morality and Law, (Karachi: Asia Publshers, 1986), I 19.
} 
analogis (qiyas), atau deduksi dari kaedah-kaedah umum syariah (maqasid syari'ah). ${ }^{29}$

Pada akhirnya, keadilan mengacu pada upaya hakim untuk menemukan kebenaran dan memberikan hukum jika ada pelanggaran yang tidak ada aturan tegasnya secara formal. Hal tersebut adalah bentuk dari keadilan prosedural. Keadilan prosedural adalah aspek ekternal hukum, tempat keadilan substantif direalisasikan. Tanpa adanya keadilan secara prosedural, keadilan substantif hanya akan menjadi teori-teori yang tidak menyentuh realitas masyarakat. Meskipun demikian, selain keadilan, nilai kepastian dan kemanfaatan hukum juga penting untuk dipertimbangkan dalam penegakkan hukum. ${ }^{30}$

\section{Penutup}

Keadilan selalu dijadikan sebuah nilai ideal dalam pembuatan maupun pelaksanaan hukum, meskipun sebagai konsep yang abstrak keadilan seringkali dipahami tanpa batasan yang jelas. Perkembangan pemikiran hukum Islam pun tidak dapat dilepaskan dari konsepsi keadilan.

Keadilan adalah sebuah konsep abstrak yang memiliki kekuatan besar dalam membentuk cara pandang. Keadilan memiliki cakupan makna yang luas dan memasuki berbagai bidang: ekonomi, politik, hukum, dan teologi. Islam pun sangat peduli dengan masalah keadilan. Konsepsi keadilan akan terus berkembang sejalan dengan perkembangan sosial. Pemaknaan terhadap keadilan menjadi bagian dari arus budaya dan dinamika sosial, sehingga pemaknaannya akan selalu baru dengan tanpa meninggalkan pencapaian-pencapaian yang telah dihasilkan oleh

\footnotetext{
${ }^{29}$ Abdul Wahhab Khallaf, Usul al-Fiqh, (Beirut: Dar al-Qalam, 1978), I05-I 12.

${ }^{30}$ Gustav Radbruch mengatakan bahwa hukum yang baik adalah ketika hukum tersebut memuat nilai keadilan, kepastian hukum dan kemanfaatan. Sekalipun ketiganya merupakan nilai dasar hukum, namun masing-masing nilai mempunyai tuntutan yang berbeda satu dengan yang lainnya, sehingga ketiganya mempunyai potensi untuk saling bertentangan dan menyebabkan adanya ketegangan antara ketiga nilai tersebut (Spannungsverhaltnis). Theo Huijbers, Filsafat Hukum dalam Lintasan Sejarah, (Yogyakarta: Kanisius, 1993), 161.
}

\section{\begin{tabular}{l|l}
341 & al-Daulah \\
Vol. A. no.2. Oktober 2014
\end{tabular}}


para generasi terdahulu. Konstruksi hukum dan keadilan dalam Islam pun tidak dapat dilepaskan antara moralitas dan kepercayaan transcendental, disebabkan aspek-aspek tersebut saling bertautan.

\section{Daftar Pustaka}

Ahmad, Manzoor. Morality and Law. Karachi: Asia Publishers, 1986.

Alam, Andi Syamsu. "Peningkatan Kualitas Putusan Hakim Peradilan Agama Tingkat Pertama dan Tingkat Banding", dalam Majalah Varia Peradilan, Jakarta: Ikatan Hakim Indonesia (IKAHI), Tahun Ke XX No. 239 Agustus 2005.

Angkasa. Filsafat Hukum. Purwokerto: Universitas Jenderal Soedirman, 2010.

Bakri, Asafri Jaya. Konsep Maqashid Syari'ah Menurut al-Syatibi. Jakarta: Logos wacana Ilmu, 1997.

Buti (al-), Muhammad Said Ramadhan. al-Dawabit al-Maslahat fi alSyariah al-Islamiyyah. Beirut: Muassasah al-Risalah, 1977.

Dahlan, Abdul Aziz, et. all (editor). Ensiklopedi Hukum Islam. Jilid 2, Jakarta: PT Ichtiar Baru Van Hoeve, 1997.

Daraini (al-), Fathi. al-Manahij al-Usuliyyah fi Ijtihad bi al-Ra'yi fi alTasyri'. Damaskus: Dar al-Kitab al-Hadis, 1975.

Friedrich, Carl Joachim. Filsafat Hukum Perspektif Historis. Bandung: Nuansa dan Nusamedia, 2004.

Ghazali (al-), Imam Abi Hamid Muhammad bin Muhammad. AlMustasfa Min 'Ilm Al-Usul. Beirut: Dar al-Fikr, t.th.

Habermas, Jürgen. Justification and Application: Remarks on Discourse Ethics. Oxford: Polity Press, 1990.

-. Moral Consciousness and Communicative Action, Cambridge: MIT Press, 1990.

Halim, A. Ridwan. Pengantar Ilmu Hukum Dalam Tanya Jawab. Jakarta : Ghalia Indonesia, Jakarta, 2005. 
Huijbers, Theo. Filsafat Hukum dalam Lintasan Sejarah. Yogyakarta: Kanisius, 1993.

Ibn Qayyim. I'lam al-Muwaqi'in Rabb al-'Alamin. Beirut: Dar al-Jayl, t.th.

Kamali, Muhammad Hashim. Shari'ah Law: An Introduction. Oxford: Oneworld Publications, 2008.

Khallaf, Abdul Wahhab. Ushul Figh. Beirut: Dar al-Qalam, 1978.

Mas'ud, Muhammad Khalid. Islamic Legal Philosophiy. Islamabad; Islamic Research institute, 1977.

Muslehuddin, Muhammad. Philosophy of Islamic Law and the Orientalists. Delhi: Markazi Maktaba Islami, 1985.

Nabhani (an-), Taqiyuddin. Asy-Syakhshiyah al-Islâmiyyah, Ushûl alFigh. Al-Quds: Min Mansyurat Hizb at-Tahrir. 1953.

Praja, Juhaya S. Filsafat Hukum Islam. Bandung: Pusat Penerbitan Universitas LPPM UNISBA, 1995.

Qardhawi, Yusuf. Figh Maqasid Syari'ah. Pustaka Al-Kautsar, 2007.

Qutb, Sayyid. "Keadilan Sosial dalam Islam", dalam John J. Donohue dan John L. Esposito, Islam dan Pembaharuan, Terj. Machnun Husein, Jakarta: CV Rajawali, 1984.

Rahman, Afzalur. Doktrin Ekonomi Islam. Jilid 1, Terj. Soeroyo, Nastangin, Yogyakarta: PT Dana Bhakti Wakaf, 1995.

Rasuanto, Bur. Keadilan Sosial: Pandangan Deontologis Rawls dan Habermas, Dua Teori Filsafat Politik Modern. Jakarta: Gramedia, tt.

Rato, Dominikus. Filsafat Hukum, Mencari, Menemukan, Dan Memahami Hukum. Surabaya: LaksBang Yustisia, 2010.

Salam (al-), Izzuddin Ibn Abd. Qawa'id al-Ahkam fi Masalih al-Anam. Beirut: Dar al-Jail, t.th.

Syatiby (al-). al-Muwafaqat fi Usul al-Syari'ah. Kairo: Mustafa Muhammad, t.th.

Zahrah, Muhammad Abu. Ushul al-Fiqh. Mesir: Dar al-Fikri alArabi, 1958.

Zuhaili, Wahbah. Ushul al-Figh al-Islami. Beirut: Dar al-Fikr, 1986. 